\title{
Chapter 16 Trust Busting the Tech Giants?
}

In light of the many problems caused by the tech giants' somewhat opaque transformation of the public sphere, it is quite necessary to ask the question of how they can be brought to show greater accountability when it comes to the public sphere. It is not just a matter of pushing a few buttons-there are elementary structural defects to the very setup. There are two ways to change this: the coercive or the voluntary. The first is often discussed in terms of the increasingly monopolistic behavior of the giants. We have already touched upon their dominant role in the market. The present situation is a far cry from the anarchist-or free-market liberalist-Internet of the 1990s, with its diversity of users and small companies all competing with each other. The dot-com bubble burst around the turn of the millennium and wiped out many of the small firms, helping to usher in the next phase, the 2000s. Here, a few companies gradually gained control of the market, only to become the world's richest during the 2010s. Scrooge McDuck's amazing career from shoeshine boy to the richest duck in the world has long been replaced by the story of Mark the Nerd who founded Facebook in his college dorm room in 2004, and long before turning 30 became one of the world's most wealthy and powerful people. Facebook and Google are approaching a duopoly in the online advertising market based on non-paying

F. Stjernfelt, A. M. Lauritzen, Your Post has been Removed, https://doi.org/10.1007/978-3-030-25968-6_16 
users, with Microsoft and Apple bordering on duopoly in the field of software, and finally Amazon with its near-monopoly on Internet trade. The latter is less central to freedom of expression, but still includes a relevant dimension, as the size and market dominance of Amazon has made the company's bookstore capable of putting unprecedented pressure on its suppliers - the publishing companies. The story of Jeff Bezos is well known, how he saw the enormous possibilities of Internet trading and decided to start from one corner: books. It was an industry of durable, easily transportable goods with a distribution network then dominated by small local players. It turned out to be the perfect place to launch a disruption of trade patterns through e-commerce. Amazon grew explosively and managed in but a few years to establish itself as a key player in the sales and distribution of books in many countries. Among the secrets to the company's success was placing its headquarters in Seattle, in sparsely populated and remote Washington State, which meant that mail order buyers outside of the state could avoid taxes, allowing Amazon to undercut the prices of local bookstores. In the longer run, Amazon's strength allowed the company to put pressure on the pricing policies of publishing companies.

This became clear in the case of Amazon's dispute with large French publishing group Hachette, which also owns a number of American publishing houses. In April 2014, the contract between the two was set for renewal negotiations when Amazon came up with a new demand: Hachette was to reduce the price of most of its e-books to 9.99 USD. Hachette refused-and, as a counterstrike, Amazon made it more difficult to purchase Hachette's books through its website. ${ }^{1}$ The books could no longer be pre-ordered on Amazon, and if a buyer managed to order a Hachette book, the delivery time

\footnotetext{
${ }^{1}$ This does not, however, make Hachette a persecuted company, free of any guilt. In 2012, the US Department of Justice filed an antitrust case against Hachette and Apple, accusing the two companies of having made clandestine deals to keep e-book prices artificially high. Hachette concluded a settlement while Apple took the case which it ended up losing.
} 
was extended to several weeks. Hachette is a major player with revenue of around 10 billion USD, making it one of the five largest publishing groups in the US - but still a dwarf as compared to Amazon's turnover in the trillions. Amazon's blackmail tactics gave rise to a protest by 900 authors, led by Malcolm Gladwell and Philip Roth who claimed that Amazon deliberately hurt both Hachette and the authors' own opportunity for income and freedom of expression. At a price of 9.99 USD, Amazon not only deflated the price of books, but indirectly manifested the company's perception of the value of books - the cost of producing a book is based exclusively on print, inventory and shipping and not on the intellectual capital, creativity and years of work going into it. The authors called for Amazon to be reported to the US Department of Justice in order to file an antitrust suit.

Clearly Amazon could only get away with its pressure policy because the company has a quasi-monopoly in the field of online book sales. As things had evolved, Hachette was in no position to simply turn away and look for another distributor. In June, Amazon wrote to a handful of selected Hachette authors and offered them $100 \%$ payments for the duration of the lawsuit-arguing publicly that publishers like Hachette should simply cease to exist entirely now that people could go ahead and publish their books online. The outcome of the conflict was a compromise: Hachette retained the right to price its own products, but a number of strong incentives to put promotional offers up on Amazon were imposed on them. Over the duration of the suit, Hachette's revenue fell by $18.5 \%$ against the previous year-illustrating the power of a company like Amazon, which controls more than half of US book sales. The case against Hachette is not the only one in which Amazon has used special methods towards its suppliers, and one might fear that Amazon, with its extraordinary economic muscle, is slowly gaining control over which books can be published and at what price-a situation with obvious problems for freedom of speech. Today, Amazon itself is already the largest publisher of books in the US, primarily of popular fiction, and is currently in the process of 
establishing itself in neighboring industries, as a producer of television shows, etc. Is it a good thing that the same monopoly company not only sells and distributes content, but produces it as well? Publishers today already have no alternatives to Amazon - could the next step be authors who have no real alternative channels of publishing and distribution?

The role and position of Amazon are easily to understand-it is the world's largest retailer. But how should companies like Google and Facebook be categorized? On some occasions Facebook calls itself a neutral "platform for all ideas", on others a "community" based on certain values. Others have called it a "means of communication" or a "social network", and still others have used the words "media" or a "social media", while others claim it is a piece of infrastructure - a "public utility". This battle for categorization is by no means a simple matter of semantics - it is crucial to how we can imagine a solution to the problems of tech giants discussed in this book. As stated by Senior Editor of New York Magazine, Max Read, there is real difficulty in describing what kind of social, cultural and economic phenomenon Facebook really is: "Over the past year I've heard Facebook compared to a dozen entities and felt like I've caught glimpses of it acting like a dozen more. I've heard government metaphors (a state, the E.U., the Catholic Church, Star Trek's United Federation of Planets) and business ones (a railroad company, a mall); physical metaphors (a town square, an interstate highway, an electrical grid) and economic ones (a Special Economic Zone, Gosplan). For every direct comparison, there was an equally elaborate one: a faceless Elder God. A conquering alien fleet. There are real consequences to our inability to understand what Facebook is."2 Zuckerberg's May 2017 "listening tour" to all US states was reminiscent of a visit from the Pope, and led to speculation as to whether he was preparing to run for President.

Nevertheless, a categorization must take into consideration the company's monopoly-like status. In the spring of

\footnotetext{
${ }^{2}$ Read, op.cit.
} 
2018, at the hearings in the US Congress and the European Parliament, Zuckerberg waved off critical questions about Facebook's alleged monopoly status. He claimed that the average American communicates through eight different apps-but at the same time, he was unable to name a single competitor who offered services to the user similar to those of Facebook. Zuckerberg's argument is misleading - it is a bit like if the owner of all the roads in a country were asked if he had a monopoly and the owner replied: Everyone is moving in at least eight ways - they crawl, walk, run, ride a bike, fly, drive a car, ride the bus and ride the train. Needless to say, Zuckerberg's contention aligns badly with his own explicitly stated ambitions on the company's behalf: to form a global community.

A growing number of observers find that market dominance of the tech giants must be fought through antitrust legislation. In a US context, antitrust legislation dates back to the decades around 1900, when many trusts had sprung up within a number of industries. Many companies from the same industry branches had joined forces, been bought up or entered into agreements, especially on price regulation. Theodore Roosevelt (US President 1901-09) stands out as the strongest anti-trust fighter. As early as 1890, the Sherman Antitrust Act was adopted, and in 1898 Roosevelt's predecessor William McKinley founded the U.S. Industrial Commission on Trusts, which then summoned Andrew Carnegie, John D. Rockefeller, and Charles M. Schwab to a hearing. In 1902, Roosevelt challenged railroad company Northern Securities, led by business tycoons such as J.P. Morgan and James J. Hill. The case went all the way to the Supreme Court, which in 1904 ordered Northern Securities split up into smaller companies. More than forty trusts were dissolved during the Roosevelt era. The trust-busting campaign peaked under Roosevelt's successor William H. Taft, who broke more than ninety monopolies in his Presidential term in the years around 1910. In the presidential election of 1912, trustbusting was the central theme, and Taft, who at the time had now developed a plan for state leadership of commerce and pro- 
duction, lost the election to Woodrow Wilson who ran on an anti-trust agenda informed by anti-trust lawyer Louis Brandeis as his advisor. ${ }^{3}$

One of the most famous cases was the one filed against Standard Oil, the dominant oil company of the times, owned by four families and headed by John D. Rockefeller. As early as 1890 , it controlled $88 \%$ of the oil trade. In 1906, an antitrust suit was brought against Standard Oil, and it was sentenced to split up into 34 locally-rooted companies, among them later giants Mobil, Chevron and Exxon. The US Supreme Court approved the split-up in 1911. From 1916, Louis Brandeis sat on the Supreme Court, and along with Oliver Wendell Holmes he became famous for a radical interpretation of the First Amendment: that freedom of expression should be curbed by the State only in cases where a concrete situation presented a "clear and present danger".But Brandeis was also a fierce advocate of antitrust legislation, deriving from James Madison's view that power concentrations in a market were not only an economic but also a democratic and political issue: citizens should be able to control the political power of large privately-owned operators.

Brandeis' activist anti-monopoly position on the Supreme Court was later filled by Thurman Arnold, who led F.D. Roosevelt's anti-monopoly campaign around World War II. Arnold, however, increasingly endorsed efficiency-based arguments, i.e., that competition ensured a level of efficiency lost in monopoly formation. With his focus on efficiency and price formation, Arnold weakened public interest in the political role of monopolies. The legacy of Brandeis, however, was definitively broken in the 1970s and 1980s, by economists of the Chicago school, led by Richard Posner and influential Yale economist Robert Bork. In his landmark book The Antitrust Paradox from 1978, Bork argued that often consumers actually benefit from company mergers, as they can lead to better and cheaper goods, making antitrust legislation appear economically irrational in many cases. Therefore,

${ }^{3} \mathrm{Wu}(2018)$ p. 76. 
Bork's argument was that antitrust decisions should only consider the matter economically, that is, from the point of view of the consumer and of price formation - and not from the point of view of ensuring competition, preventing power concentration, securing democratic control, etc. This attitude gradually became dominant in the US Supreme Court and would turn out to play an important part in the deregulation of the economy from the 1980s and on.

In the wake of the emergence of tech giants, today a new movement of "neo-Brandeisians" is growing-a movement which argues for the resumption of antitrust legislation with a broader legal base. ${ }^{4}$ Advocates are also called "hipster antitrusters" and include people like Lina Kahn, Tad Lipsky, Tim $\mathrm{Wu}$, and Barry Lynn. ${ }^{5}$ This position is gaining support in parts of the Democratic Party, for instance by Senator and attorney Elizabeth Warren, who is calling for action against monopolies: "In many ways, tech monopolies are similar to the oil and sugar and railroad trusts of the 19th century. And antitrust enforcers have the tools to stop tech companies from engaging in practices that choke off competition, but only if they use them. But there's one key difference between the 19thcentury trusts and today's tech companies, and that's data. Companies today gather more data on everything from where we work to where we shop, to our political views, to what we eat for breakfast. There's this belief, when it comes to tech companies, that when people don't pay up front, there's no antitrust concern. But that's a myth. Data is power. And data allows companies to push tailored advertisements to both shape and drive our preferences, and ultimately to benefit the corporation's bottom line. That's why it's critically important that antitrust enforcers focus on the ways data can be used to undermine competition." ${ }^{\prime \prime}$

\footnotetext{
${ }^{4}$ Cf. Khan (2018).
}

${ }^{5}$ The nickname was invented by one of their opponents, Konstantin Medvedovsky 2018, "Hipster Antitrust-a Brief Fling or Something More?" Competition Policy International. 04-17-18.

${ }^{6}$ Quoted from Zornick, G. "Elizabeth Warren's 'Big Fight' Against Monopolies" The Nation. 02-15-18. 
However, there are also many Republicans who see the danger-not least because of signs of indirect support of the tech giants for the Democrats. An example is Republican political campaign strategist Eric Wilson, who speaks on behalf of monopoly regulation of the companies due to his own experience with Facebook's acceptance of political ads based on "fake news": "Regulation should include limits on the information Facebook may gather on its users and subsequently sell to advertisers, greater oversight and transparency related to its compliance with federal election laws and more cooperation with researchers about the adverse effects of its various platforms on individuals and communities. More broadly, the government should begin looking into breaking Facebook into smaller entities to allow for greater competition and more consumer-friendly practices in the online advertising, publishing and communications spaces."7

A strong political voice realizing the manifold problems with the tech giants is Senator Mark R. Warner (D) whose white paper "Potential Policy Proposals for Regulation of Social Media and Technology Firms" appeared in July 2018. Here, Warner advocates a number of policies for regulating the excesses of tech giants. He sets out with emphasizing the monopoly problem: :"[...] the rise of a few dominant platforms poses key problems for long-term competition and innovation across multiple markets, including digital advertising markets (which support much of the internet economy), future markets driven by machine-learning and artificial intelligence, and communications technology markets." 8 Warner's detailed list of proposals include a GDPR-like law in order to protect the privacy of users; making tech algorithms more transparent and accessible to government audit; demanding data portability between platforms; making tech firms liable for defamation referring to existing state tort laws; requiring that automatized activity like bots is explicitly

\footnotetext{
${ }^{7}$ Wilson (2018).

${ }^{8}$ Warner, M. R. "Potential Policy Proposals for Regulation of Social Media and Technology Firms" Whitepaper, Axios. 07-30-18.
} 
labeled as such; the development of educational and public policies to build media literacy among users.

It is hardly surprising that dominant Silicon Valley figures like Peter Thiel-Facebook's first major investor and still an executive board member-run counter to such views by stating that monopolies actually deserve their position in the market. By this line of argument, a monopoly is the logical result of their victory in the competitive game, a competition which is then rendered unnecessary. Thiel is a radical libertarian and by definition he considers states-even democracies - as the enemy: "I no longer believe that freedom and democracy are compatible." ${ }^{9}$ Monopolies are, however, the very thing that allows him to create a free world protected against taxation and state intervention. By contrast, Thiel speaks directly against competition between suppliers of the same type of product, as it will only eat away profits. ${ }^{10}$ His line of thought makes it clear that devotion to the free market is no longer the same as devotion to free competition.

A leading figure of the neo-Brandesian movement is Barry Lynn from the Open Market program at the think tank New America. After supporting antitrust legislation against the tech giants, he was fired in August 2017, shortly after the EU fined Google. According to the New York Times, the reason behind the firing was that Google was among the sponsors of New America, and Google CEO Eric Schmidt seems to have personally demanded Lynn's departure. President and CEO of New America Anne-Marie Slaughter shut down the entire Open Market program and emailed Lynn that the decision was "in no way based on the content of your work" but at the same time accused Lynn of "imperiling the institution as a whole."11 The wealth of the tech giants enables them to support a very large number of think tanks, NGOs and civil

${ }^{9}$ Thiel, P. "The Education of a Libertarian" Cato Unbound. 04-13-18. ${ }^{10}$ Thiel (2014) p. 35ff.

${ }^{11}$ Vogel, K.P. "Google Critic Ousted from Think Tank Funded by the Tech Giant" New York Times. 08-30-17. 
society organizations of many different political orientationsnot to mention both major political parties, of course. They carry out this support based on the assurance that it will make them influential regardless of the outcome of the next elections. In this light, it is no encouragement to free speech that giant power may be used to get rid of critics representing nominally independent think tanks, which are co-sponsored by giants. One might ask: could a classic high-quality medium with a long tradition of serious investigative journalism, such as Washington Post, now really show critical interest in the monopoly behaviors of tech giants? Since 2013, The Post has been owned by Amazon CEO Jeff Bezos. An uncanny parallel is Facebook's removal of ads by Elizabeth Warren calling for Facebook break-up in March 2019. Warren said, in an ad, "Three companies have vast power over our economy and our democracy. Facebook, Amazon, and Google. We all use them. But in their rise to power, they've bulldozed competition, used our private information for profit, and tilted the playing field in their favor." "12 After public outrage, a Facebook spokesperson explained that they removed Warren's ads because they violated their policies of corporate logos. They later restored the ads.

But there are important parallels between the strong antitrust legislation in the US during large parts of the 20th century and the increasing problems with the tech giants. They have not yet been seriously subject to antitrust scrutiny, possibly due to the misunderstanding that because users get the service for free, there is nothing to get at-echoing Bork's perspective on the perspective of consumer prices. However, this ignores that in the tech giant setup, the consumer is not the user; rather, the paying advertisers are. The prices they negotiate when dealing with tech giants are hardly exposed to free competition, judging by the way things are now.

We have already described how the railway monopoly was trust-busted-a related case concerns freight transport by

\footnotetext{
${ }^{12}$ Lima, C. "Facebook backtracks after removing Warren ads calling for Facebook breakup" Politico. 03-11-19.
} 
rail. It is obvious that a railway owner who also owns production companies could be inclined to give priority to transport of its own products in the freight wagons. Antitrust legislation prohibited this by adopting a principle of neutrality, so that goods must be shipped in the order they arrive, treating all customers equally and charging the same prices for the same services. This is often called a ban against "vertical integration" - that is, against allowing companies to integrate the production of goods with higher-level distribution and processing of said goods. The ban serves to block the option of giving priority to one's own products over the competitor's. The first major monopoly case in the Internet age, against Microsoft in the 1990s, in fact had exactly that characteristic. The argument was that the company combined its Windows operating system with its own browser, Internet Explorer, so customers were not free to use the browser software they wanted. It was considered so-called illegal "tie-in" in which the buyer of a product was forced to also buy another product, thus excluding other browser developers such as then-popular Netscape, from access to consumers. Microsoft claimed that the browser was not an independent product but an independent "feature" inside the operating system. In 1999, the Department of Justice won the case, obliging Microsoft to split up into two companies. In 2002, however, appeals by Microsoft led to a settlement which held that making all "tie-ins" illegal would hamper technological advances. On the other hand, the settlement obliged Microsoft to share with competitors key components of its software code, and set up a committee to make sure it happened. In the US, this was the last major antitrust case, and during the presidency of George W. Bush, not a single trust was broken. Thus, the actual gilded age of tech giants occurs in a legal vacuum where the US government seems to have forgotten its century-long antitrust legacy.

The EU, however, continues along the antitrust lines which Europe originally learned from the US. Of a similar nature as the Microsoft case is the EU Commission's recent case against Google. It made the accusation that, when users 
searched for a given product, Google prioritized its own price comparison feature for shopping over that of competing services. In August 2017, the EU, led by Commissioner Margrethe Vestager, fined Google 2.7 billion USD for competition abuse. A January 2017 survey by Wall Street Journal showed that $91 \%$ of searches on Google resulted in ads for one of Google's own products at the top of the rankings. ${ }^{13}$ Currently, the EU Commission has ongoing cases against both Google and Apple. On several occasions, Vestager has aired classic antitrust views - simply proposing a split-up of Google into several independent companies. On July 18, 2018, the EU issued its biggest fine ever, 5 billion USD. Once again, it was Google that received the fine. The reason for this one relates closely to the Microsoft case from around the turn of the millennium. Since 2011, Google has made use of its operating system Android depend on the use of Google's own native apps. This so-called "bundling" takes away the user's freedom to choose between other apps, according to Commissioner Vestager. The verdict gave Google 90 days to change its ways, on pain of daily penalties of up to $5 \%$ of its company revenue - to no one's surprise, the company appealed the decision. ${ }^{14}$

These issues are also deeply tied to the entire debate on net neutrality. The term refers to the idea that the Internet should generally be structured so that all content is treated according to the same principles, and that no content is given priority over other content when network providers process that content. Net neutrality aims to ensure that different users, content, websites, platforms, applications, equipment or methods of communication are treated equally and are not,

\footnotetext{
${ }^{13}$ When entering the search "phone", up came a Google Pixel, the search "laptop" resulted in a Chromebook, "watches" an Android Smartwatch etc., cf. Nicas, J. "Google Uses Its Search Engine to Hawk Its Products" Wall Street Journal. 01-19-18.
}

${ }^{14}$ Anneberg, M, Nielsen, R. D. \& Albrectsen, N. "Vestager straffer Google med milliardbøde" TV2 Udland. 07-18-18. 
for example, subject to different payment or priorities during the process. This is the Internet's heir to the concept of "common carrier", which dates back to the legal basis of the transport of goods and phone conversations (Communications Act of 1934). A number of European countries have legallybased net neutrality, but in the US the concept is disputed. In 2015, the United States Federal Communications Commission (FCC) decided to allow different processing speeds, but at the same time it reclassified the web as telecommunications. This reclassification put the Internet within the scope of the principle of neutrality for common carriers. Under President Trump, however, the FCC has reclassified the web back to public infrastructure. Thus, in June 2018 the principle of net neutrality was lifted. Some observers argue that continued growth in bandwidth have, until now, made the subject less relevant in practice. Legally and politically, the issue is highly controversial, and a more detailed analysis falls outside the scope of the present work - not least because net neutrality refers to internet service providers rather than our focus here: the tech giants.

As a precedent of net neutrality, the status of telephone companies calls to mind another classic antitrust case from the US, which is even more similar to the tech giants than Northern Securities railways were. It concerned telephone company AT\&T. During the 1880s, this company emerged from Bell Telephone Company, named after Alexander Graham Bell, inventor of the telephone. In the early years of the telephone, competing telephone companies each maintained their own cable network in such a way that a given street in US could have many telephone poles and wires from several competing companies - an example of what is often called "destructive competition". In such cases, a market can become unstable, and even in the ideal case of symmetrical competition between equal competitors of equal sizes, costs will occur that are absent in the case of monopolies (e.g. costs related to coordination and negotiations between 
companies). ${ }^{15}$ Just like the network-driven Internet providers, customers back then had an obvious interest in being able to get in touch with as many other phone owners as possiblethis early version of the network effect naturally concentrated customers in a few large companies. As early as 1907, AT\&T had a 50\% market share, a share quickly approaching a de facto monopoly. Initially, the government followed the same procedure as against Standard Oil and advocated for a split-up, but in 1913 a compromise was reached. In this deal, known as The Kingsbury Commitment, AT\&T's natural monopoly was acknowledged. In return for the Government's promise not to split up the company, AT\&T agreed to the following: give up its control of the telegraph company Western Union; stop acquiring additional companies without the permission of the authorities; commit to serve all customers, even remote ones; allow other non-competing telephone companies to connect with AT\&T's attractive long-distance telephony. At the time, the company had been criticized for being able to eradicate competitors by denying them the right to connect to AT\&T's long-distance service. During the 1920s and 1930s, the authorities allowed for AT\&T to acquire smaller telephone companies but simultaneously, the company was subject to government price controls.

Another antitrust case, in 1949, led to a new compromise in 1956. It made the company agree to run the national telephone network only and thus not move into neighboring industries. The company's development department, the famous Bell Labs, was required to share its patents freely. The roots of Bell Labs went all the way back to Bell's very own laboratory, having been owned by AT\&T and Western

\footnotetext{
${ }^{15}$ Interestingly enough, following his detailed review of the theory of natural monopolies and the American telecommunications industry, Sharkey (2008) (orig. 1982, p. 213) concludes that it is difficult to determine whether this industry is a natural monopoly, even though it has many of the features predicted by abstract theory of economics (decreasing marginal costs, many "sunk" establishment costs, lower prices of a monopoly than a duopoly, etc.).
} 
Electric since the 1920s. It became one of the most important research labs of the 20th century, employing several Nobel Prize-winning researchers. Many important breakthroughs and inventions can be traced back to Bell Labs: radio astronomy, the transistor, some of the first American computers, the photocell, the communication satellite, the solar panel, the laser, several of the early computer languages, the quantum Hall effect, the digital mobile phone, etc. Its impact goes all the way up to today; it is now owned by Nokia. There is an irony to the fact that Bell Lab's freely available patents became central to the early development of the personal computer. As Jonathan Taplin writes, today's enormous tech monopolies rest on technologies which the giants themselves were free to access because of government antitrust action. The appearance of the first mobile phones in the 1960s was what finally led to a split-up of the Bell System in 1982. The newly arrived mobile phones did not depend on the cable network, and AT\&T used its monopoly to try to prevent those phones from connecting to the company's network by increasing the price for access. As a result, calls were made in 1982 for the separation of local telephone networks - the socalled "Baby Bells" - and Bell Labs was finally sold off in 1996.

The AT\&T example is prototypical for the discussion of "natural monopolies"16 The idea is that certain products or services are naturally inclined towards monopoly. These are products where the initial costs of establishing a company's services are high, but where the marginal costs of recruiting new customers are low. This makes the marginal income increase with the number of customers. That is why earnings can explode once the company is established. Hence, new customers can be attracted at a lower price than that of new companies, who first have to pay the establishment costs (e.g. cable networks). The result is often that first movers turn into natural monopolies. At the same time, these companies are

\footnotetext{
${ }^{16}$ And which is chosen by Sharkey as an example to analyze.
} 
able to provide their services at a lower price than would two competing companies (if there were two competing phone companies, all consumers would need two telephones to get the same service that one could provide, which would be more expensive for the consumer). ${ }^{17}$ A product with the characteristics of a network may be considered a natural monopoly candidate thanks to the network effect: all customers want to belong to that company which offers the highest possible number of other customers. This effect is evident, since the very service offered is a connection between customers, and the inclusion of an additional customer is only a marginal expense once the network is established. Many natural monopolies have the traits of infrastructure like water suppliers, power providers, sewerage, road networks, railways and telephone networks.

The US Government-since 1890-developed a long antitrust tradition. Therefore, the 1913 compromise with AT\&T may seem surprising-probably the decision makers realized that telephony was a natural monopoly. It would be counterproductive and artificial to insist on maintaining many competing telephone companies, each operating its own cable network (it is no coincidence that what split up AT\&T 100 years after its founding was phones with no need for cables). In return for this acknowledgment of the AT\&T monopoly as public infrastructure, the government regulated its acquisition of new companies, introduced price controls, prohibited the company from moving into neighboring industries and ultimately demanded the company make its research and patents public.

It is possible to view Google and Facebook as natural monopolies, except they no longer just operate in American territory, but worldwide. Thus, any possible regulation efforts in the foreseeable future must take place on a nation-state basis. These two companies have a market share similar to that of Standard Oil when it was charged as a monopoly in the 1890s (and even higher than Standard Oil's market share

${ }^{17}$ See Sharkey (2008) chs. 1 and 9. 
at the time of the verdict). Also, they are similar to AT\&T in a number of ways: they deal in communications infrastructure; they base their strength on the network effect; they shield themselves behind the ongoing acquisition of competitors; they continuously expand their field of activity by buying and absorbing companies from neighboring industries.

Thus, certain options for regulating the monopolies of tech companies appear on the horizon. Barry Lynn categorizes tech giants as public utility infrastructure and points to two kinds of solutions: either splitting up monopolies or regulating them. ${ }^{18}$

The former solution is thus splitting up the companies. Due to their character of natural monopoly, this could not follow the Standard Oil model of splitting into smaller companies of the same kind, only divided according to geographical location. It would make no sense to split up Google into local, competing search engines Giggle, Gaggle and Guggle. Pretty much the same goes for Facebook. Yet, they could be split up by being forced to sell off some of the many companies they have acquired and integrated as additional services (a pattern which could be accused of "vertical integration"), while still retaining their core service as a natural monopoly.

Another even more reasonable approach (and one which does not exclude the first) would be the recognition of a natural monopoly on information searches and on "connecting people", or however Facebook will end up being defined. As in the case of AT\&T, ${ }^{19}$ such a recognition would then come at a price, for instance some of the following: public price control (on ads prices); net neutrality and non-discrimination of customers and users; publication, public discussion and audit of algorithms; balancing off community standards at least so they are not stricter than local legislation; public control of

\footnotetext{
${ }^{18}$ Brandom, R. "The Anti-monopoly Case Against Google" The Verge. 09-05-17.

${ }^{19}$ As noted by Gillespie (2018) p. 44f, it is striking how it was agreed upon to give the tech companies comprehensive legal protection under the "Safe Harbor Act" without balancing things by giving them obligations.
} 
and clear appeal options regarding the removal of criminal content and ditto users; a transparent procedure around copyright enforcement; transparency requirements for the publication of political ads; sharing of profits with external content providers who attract online traffic for the ad business; free access - as in the case of Bell Labs - to the results and patents of the companies' wildly expanding research departments. Companies like Google and Facebook do not produce and edit the content posted by their users - but there is one service that they actually edit and control, namely ads. Their origin, funding, content and targeting could be subject to greater control.

Obviously, as mentioned above, there are states with significantly stricter legislation on free speech than the Facebook and Google standards, and several of these states regularly push, restrict, harass or shut down these services (e.g. Turkey, Pakistan, Saudi Arabia and several other Muslim states). Others even completely disconnect the services from operating and create alternative, highly-controlled copycat services (as in China). It is not within the scope of this book to go into detail about the many different struggles and compromises that tech giants have faced when dealing with non-democratic states. In such countries, key freedom of speech issues are "classical" government and/or religious restrictions on free speech. In those cases, problems are only partly caused by tech giants. On the contrary, they have had a tendency to support freedom of speech when confronted with strict local political-religious gag laws and regulations. Here, Orwell is more relevant than Huxley. Especially in the early days, the web and tech companies actually made a whole new level of free speech possible for many groups in such countries, evidenced by Google top leaders rejoicing the Arab Spring. However, in order to also fit in to authoritarian markets, tech giants over time have tended to increasingly bow to pressure to remove content that such countries request or push to have removed-even if they were not originally covered by the company's own standards. These disputes have been 
around for many years and will hardly be affected by the introduction of western regulation of the services. It will primarily be a matter concerning the United States and the EU, secondarily other countries with Western models of society emphasizing liberty. At present, neo-Brandeisians supporting antitrust legislation are hardly strong enough for action in the United States even though many politicians after the congressional hearings in April 2018 are gradually beginning to speak about regulation. Furthermore, a decisive player like the European Union is now weaker than when the Google cases were launched, due to the Euro and Brexit crises.

Some may argue that given the decline in American antitrust policies, the US may have a hard case trying to split up tech giants, facing now a Supreme Court with a possible republican free-market bent. But still it can be argued that even lost antitrust cases have proven helpful because companies, during the legal process, strive to accommodate their activity in order to try to alleviate consequences in case of losing. Facebook co-founder and critic Chris Hughes cites the antitrust case lost against IBM in the 1980's which nevertheless forced the company to increased openness as well as to separate hardware and software sales. ${ }^{20}$

It comes as no surprise that the tech giants are not excited about growing rumblings of monopoly control. In July 2018, in a long interview with the website recode, Zuckerberg set up a foreign policy nightmare scenario as a warning against monopoly control: “... do we want American companies to be exporting across the world? We grew up here, I think we share a lot of values that I think people hold very dear here, and I think it's generally very good that we're doing this, both for security reasons and from a values perspective. Because I think that the alternative, frankly, is going to be the Chinese companies. If we adopt a stance which is that, 'Okay, we're gonna, as a country, decide that we wanna clip the wings of these companies and make it so

${ }^{20}$ Hughes, C. "It's Time to Break Up Facebook" New York Times. 05-09-19. 
that it's harder for them to operate in different places, where they have to be smaller', then there are plenty of other companies out that are willing and able to take the place of the work that we're doing." ${ }^{21}$ Zuckerberg's argument is that monopoly control would especially harm the opportunities of US companies to operate outside the United States. It is a rather odd remark, given the natural fact that outside the US is outside the realm of American legislation. So it is hard not to see this as straw man argument, which plays on the well-known American fear of Chinese competition-and it clearly fails to address the key arguments for monopoly control in the United States.

Anti-monopoly legislation, however, is a heavy weapon and should be used carefully. Voices against any government interference into the economy are quick to label neoBrandeisians like Lynn as communists, supporters of planned economy, sentimental and populist protectors of small and unprofitable businesses, driven by envy of companies who have done well and grown big, and as anti-democratic paternalists who think they know better than the consumers, and so on. But anti-Brandeisians also put forward serious arguments that should be taken into account. In fact, this is a collision of two varieties of a free-market ideology. One sees competition as a procedure which ought to be ensured when monopolies, to a greater or lesser extent, neutralize or block competition in a given field. Such blockage implies the risk of these competition "winners" taking advantage of their strength to prevent new competition from gaining ground, to push prices up and ultimately freeze in their own inefficiency when they are no longer exposed to competition. As the market itself is unable to fight monopolies and ensure competition, the state must step in. The other emphasizes the results of competition-once a company has won a monopoly or duopoly in an industry, it is proof of the superiority of its business model and the high quality of the product, and thus there

\footnotetext{
${ }^{21}$ Swisher, K. "Recommended listening: Kara Swisher interviews Mark Zuckerberg" Recode. 07-20-18.
} 
is no need to ensure further competition. It would only take the form of harmful government interference and abuse of the market, giving artificial support to inferior products. In this view, monopolies must be protected against the greed and ignorance of the government.

Supporters of the latter position - that of anti-antitrustwill argue that if the growth of a company is restricted in order to expose the company to competition, then immediately the companies start competing against each other in an alternative battle for political influence in order to use it against the competitors. It will cause smaller companies to seek political support against the larger ones-and perhaps consequently lead to even greater concentration, only now one that enjoys political protection. This will lead to increased lobbyism activity, where the benefit of getting along well with a small group of government officials can be greater than that of improving the business model. This argument can also be expanded to address the very real problem that introducing regulation of, for example, Facebook and Google may secure these companies, insofar as due to lobbyism they are better than smaller firms at influencing regulation to serve their own purposes, just as they are likely to have more resources on their hands to implement demanding regulatory procedures. A further argument goes like this: if monopoly control is also introduced for reasons other than economic ones - for instance to promote certain political, social or democratic goals - then the point could be made that special cases would support those same objectives by making exceptions from the regulation. Such exceptions would then be subject to further lobbyism and in turn lead to more and worse concentration. $^{22}$

In light of the current high level of concentration, the point that regulation will lead to worse market concentration does not seem strong. Only on rare occasions did previous anti-

\footnotetext{
${ }^{22}$ These arguments are summarized by Manne, G. "The Illiberal Vision of neo-Brandeisian Antitrust" Truth on the Market. 04-16-18.
} 
trust interventions lead to higher concentrations. The lobbyism argument, on the other hand, is stronger. It is undoubtedly true that regulation in all its forms will give companies an even stronger incentive to try to influence the political process. Taplin cites a gloomy statistic of how many top executives have switched back and forth between Google and the White House. ${ }^{23}$ Some of them are likely to maintain a connection with or loyalty to their former employer. Anti-antitrust figures such as Law Professor Geoffrey Manne speaks as if antitrust legislation could be used indiscriminately to implement all sorts of support policies with widely different goals. This should indeed be avoided; thus monopoly suits should only be opened in case of very clear indications of destructive economic, public or political effects of the monopoly. We think that is indeed the case when looking at the tech giants, their actual management of free speech, their strong influence on democratic elections and processes, their lack of data protection, their acquisition of competitors, etc. The incentive for more lobbyism in case of antitrust intervention is undoubtedly an important factor to keep in mind-which may only be counteracted by increased transparency on and regulation of campaign support, nepotism, and corruption. In May 2019, the antitrust case received renewed impetus with an important op-ed from Facebook co-founder Chris Hughes in the New York Times. Here, Hughes recommended a breakup of Facebook, most easily accomplished by the forced sale of acquisitions like Messenger, Instagram and WhatsApp. Hughes refers to his old friend, attacking his unprecedented control of freedom of expression: "The most problematic aspect of Facebook's power is Mark's unilateral control over speech. There is no precedent for his ability to monitor, organize and even censor the conversations of two billion people." 24

\footnotetext{
${ }^{23}$ Taplin (2017) p. $129 f$.

${ }^{24}$ Hughes, C. "It's Time to Break Up Facebook" New York Times. 05-09-19.
} 
It is not within the framework of this book to get into details on how regulation can and should be drafted. But to us there is no doubt that the still more strong voices advocating reconsideration of antitrust trials against tech giants have a strong case going for them.

Open Access This chapter is licensed under the terms of the Creative Commons Attribution 4.0 International License (http://creativecommons.org/licenses/by/4.0/), which permits use, sharing, adaptation, distribution and reproduction in any medium or format, as long as you give appropriate credit to the original author(s) and the source, provide a link to the Creative Commons license and indicate if changes were made.

The images or other third party material in this chapter are included in the chapter's Creative Commons license, unless indicated otherwise in a credit line to the material. If material is not included in the chapter's Creative Commons license and your intended use is not permitted by statutory regulation or exceeds the permitted use, you will need to obtain permission directly from the copyright holder.

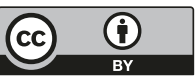

